Volume : 6

Nomor : 3

Bulan : Agustus

Tahun : 2020

E-ISSH: 2656-940X

P-ISSH: 2442-367K

URL: jurnal.ideaspublishing.co.id

\title{
Bentuk Lingual Metafora Bahasa Indonesia dalam Surat Kabar
}

\author{
Haris Danial \\ Mira Mirnawati \\ Universitas Negeri Gorontalo \\ Pos-el: harisdanial24@yahoo.co.id
}

DOI: $10.32884 /$ ideas.v \% vi \%i.284

\begin{abstract}
Abstrak
Penelitian ini bertujuan untuk mengurai cara mengklasifikasi bentuk lingual metafora dalam wacana surat kabar Gorontalo Pos serta makna yang terkandung di dalamnya. Penelitian ini menggunakan jenis penelitian kualitatif deskriptif. Hasil penelitian ditemukan bahwa dari segi bentuknya, metafora dalam wacana surat kabar memiliki bentuk yang khas yang ditunjukkan oleh kata dasar dan bentukan yang mendukung terbentuknya ungkapan metaforis. Hal ini dapat dikaitkan dengan konsep bahwa metafora merefleksikan apa yang dipersepsikan, dialami, dan dipikirkan orang tentang kenyataan dunia. Dari pernyataan ini dapat dikatakan bahwa metafora berkaitan dengan persepsi manusia terhadap apa yang dipikirkan dan dirasakannya.
\end{abstract}

\section{Kata Kunci}

Lingual metafora, wacana, surat kabar

\section{Abstract}

This study aims to parse how to classify the metaphorical lingual form in the discourse of the Gorontalo Pos newspaper and the meanings contained in it. This research uses descriptive qualitative research. The results showed that in terms of form, the metaphor in newspaper discourse has a distinctive form which is indicated by the basic words and forms that support the formation of metaphorical expressions. This can be related to the concept that metaphors reflect what people perceive, experience, and think about the reality of the world. From this statement it can be said that metaphors are related to human perception of what they think and feel.

Keywords

Lingual metaphors, discourse, newspapers

\section{Pendahuluan}

Bahasa digunakan oleh manusia untuk memenuhi kebutuhan hidup. Sebagai contoh, ketika seseorang ingin membeli sesuatu dalam memenuhi keinginannya, sudah barang tentu orang tersebut akan menggunakan bahasa yang dapat dipahami oleh orang yang menjual barang tersebut. Sama halnya dengan makanan yang menjadi kebutuhan pokok manusia, ketika seseorang merasa lapar sementara tidak ada makanan, ia akan mencari, meminta, atau membeli makanan untuk menghilangkan rasa lapar yang

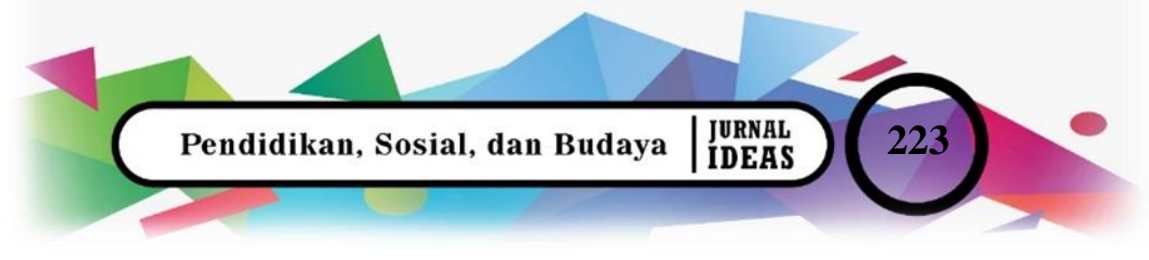


dirasakan. Ketika ia membeli atau meminta makanan, ia tentunya akan menggunakan bahasa yang dapat dipahami oleh orang yang menjual atau memiliki makanan itu. Makanan merupakan kebutuhan pokok manusia sebagaimana yang digambarkan oleh Maslow dalam piramida kebutuhan manusia (Boeree, 2006)

Dari penjelasan di atas dapat diperoleh informasi bahwa dengan adanya kebutuhan yang kompleks yang dimiliki oleh manusia, maka bahasa dapat mengimbangi setiap kebutuhan tersebut. Oleh karena itu, bahasa memiliki peranan penting dalam kehidupan manusia. Dari bahasa yang digunakan, manusia yang diajak bicara dapat mengetahui apa yang ia rasakan, pikirkan, dan alami walaupun tidak seluruhnya, karena bahasa yang digunakan tidak hanya bahasa verbal tetapi juga bahasa non-verbal (Fromkin dan Rodman, 1998; de Saussure, 1959). Akan tetapi, bahasa yang menjadi kajian penelitian ini adalah bahasa verbal yang dimanifestasikan dalam bentuk lingual. Tentunya, yang dapat dipahami adalah yang dapat diinterpretasikan dari bahasa yang digunakan.

Untuk menggunakan bahasa, seseorang mengggunakan ungkapan secara langsung yang mudah dipahami oleh pendengar. Akan tetapi, tidak sedikit manusia menggunakan ungkapan metaforis dalam berbahasa. Ungkapan metaforis merupakan ungkapan yang dikonseptualisasi yang didasarkan pada perasaan, pikiran, dan pengalaman manusia yang terjadi dalam kehidupan sehari-hari, yang menunjukkan adanya sikap atau motivasi ungkapan itu digunakan. Berdasarkan ungkapan metaforis, suatu konstruksi yang terdiri atas target dan sumber dapat diformulasikan.

Metafora (Kittay, 1987) merupakan ungkapan yang diformulasikan melalui konsep yang didasarkan pada pengalaman, perasaan, dan pikiran yang ada dalam diri manusia, khususnya dalam memahami suatu peristiwa atau entitas. Sebagai contoh, ungkapan pemberantasan hoaks merupakan ungkapan metaforis karena ungkapan itu menjadi dasar dalam memformulasikan hoaks adalah penyakit, yang terdiri atas dua komponen, yaitu 'hoaks' sebagai target 'target' dan 'penyakit' sebagai source 'sumber'. Target merupakan konsep yang dipahami berdasarkan konsep sumber.

Berdasarkan bentuk konstruksi di atas, terdapat konseptualisasi dalam ranah pengalaman yang dapat dilakukan dalam mengatasi penyakit. Penyakit identik dengan abstraksi sifat merugikan atau merusak, sehingga penyakit tersebut harus dimusnahkan. 
Volume : 6

Nomor : 3

Bulan : Agustus

Tahun : 2020

E-ISSH: $2656-940 \mathrm{X}$

P-ISSH: 2442-367X

URL:jurnal.ideaspublishing.co.id

Untuk memusnahkan penyakit, manusia dapat menggunakan berbagai cara agar dapat dihilangkan sehingga tidak muncul lagi. Bentuk konsep ini dipersepsikan sama halnya dengan kata 'hoaks'.

Hoaks merupakan penyakit yang dapat merugikan rakyat atau masyarakat, untuk itu hoaks perlu dihilangkan atau dimusnahkan. Dalam kaitannya, cara menghilangkan hoaks dikonseptualisasikan sama dengan cara memusnahkan penyakit, yaitu dengan cara memberantas. Kata memberantas diindikasikan sama halnya dengan memusnahkan sampai tuntas, sehingga hoaks tidak terjadi lagi. Hoaks merupakan fenomena sosial yang lagi trend saat ini di kalangan masyarakat yang berdampak pada seseorang yang dijadikan objek dari hoaks itu sendiri. Isu-isu yang disebarkan melalui media sosial atau media komunikasi tanpa adanya bukti yang jelas, tentunya akan berdampak besar terhadap masa depan orang tersebut. Saat ini, hoaks menjadi topik pembicaraan yang berlaku di kalangan masyarakat bahkan merupakan salah satu konsep yang dijumpai dalam wacana surat pembaca.

Kajian metaphora merupakan salah satu kajian linguistik yang menekankan pada sistem konsep (Lakoff \& Johnson, 1999). Hal itu didasarkan pada ancangan linguistik kognitif dengan memusatkan perhatian pada pandangan konseptual terhadap ungkapan metaforis yang digunakan dalam wacana surat pembaca. Selain itu, menurut Black (2006, p. 102) metafora digunakan untuk mendeskripsikan sesuatu dengan sesuatu yang lain. Selanjutnya, di dalam proses membahasakan sesuatu dalam khususnya puisi, sering juga dijumpai hal-hal yang bersifat abstrak, oleh karena itu metafora diperlukan untuk menjelaskan hal-hal yang bersifat abstrak tersebut agar lebih konkret. Hal ini menyebabkan metafora memiliki dua domain, yaitu domain yang abstrak dan domain yang konkret. Menurut Kovecses (2003, p. 8) korespondesi tersebut disusun agar tercipta sebuah pemahaman domain atau ranah yang abstrak menjadi lebih konkret. Pendapat ini juga di dukung oleh Taylor (2003, p. 134) yang menyatakan bahwa metafora dapat mengkonsepkan sesuatu yang abstrak menjadi konkret.

Metafora yang dijadikan sasaran dalam tulisan ini adalah metafora yang digunakan dalam bahasa sehari-hari yang merupakan hasil konseptualisasi gagasan, pengalaman, dan perasaan yang seringkali digunakan oleh orang baik dalam media sosial ataupun dalam konteks komunikasi secara langsung. Hal ini dimaksudkan untuk

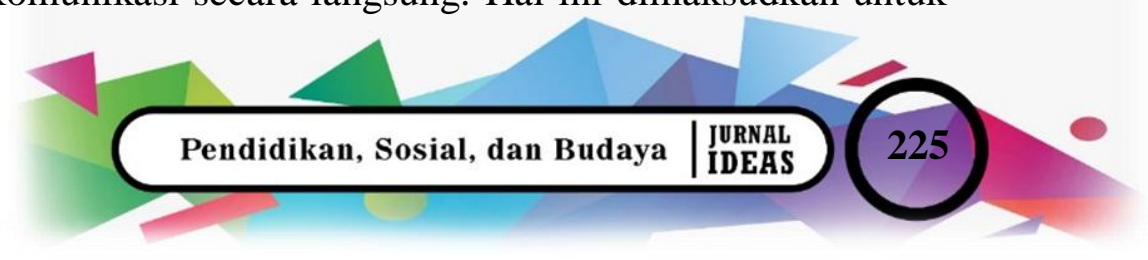


menggambarkan kajian metafora secara umum, yang ditinjau berdasarkan tulisantulisan yang relevan.

Seperti halnya dalam surat kabar, biasanya surat kabar menjadi sumber acuan dalam menentukan strategi dan kebijakan pemerintah, lembaga, maupun individu dalam mengembangkan usaha, sekaligus sebagai kontrol. Ada contoh gagasan yang diperoleh melalui Harian Gorontalo terkait dengan banyaknya Organisasi Perangkat Daerah (OPD) tidak hadir dalam gelar reses seperti yang tertuang dalam bagian surat kabar berikut ini.

1) Hargo.co.id, GORONTALO - Meskipun banyak masyarakat yang hadir saat Aleg DPRD Kota Gorontalo gelar reses, namun tetap saja menyisakan kekecewaan. Pasalnya, banyak Organisasi Perangkat Daerah (OPD) yang tak hadiri (diterbitkan oleh Van Robin, tertanggal 24 Desember 2018-08.00 wita).

Fragmen surat kabar (1) di atas menunjukkan adanya ungkapan metaforis yang dapat dikategorikan memiliki fungsi yang berbeda, yaitu pada kata 'menyisakan kekecewaan'. Ungkapan metaforis yang terkandung dalam contoh kata tersebut mengindikasikan adanya dua ranah yang dibandingkan, yaitu 'kekecewaan' dibandingkan dengan 'makanan yang tersisa'. Kemungkinan yang memotivasinya adalah pengalaman yang penulis rasakan ketika ia menyantap makanan, dan pastinya ada makanan yang tidak enak rasanya atau mungkin kebanyakan. Apa yang terjadi apabila makanan tersebut tidak enak atau porsinya banyak, pastinya makanan tersebut akan tersisa. Gambaran itu dibayangkan sama dengan kegiatan yang dilakukan oleh Aleg DPRD Kota Gorontalo yang sudah mengemas kegiatan tersebut dengan baik dan rapi, tetapi ada saja yang akan terjadi seperti halnya banyak OPD yang tidak hadir, sehingga memberi kesan kecewa bagi aleg yang menyelenggarakan kegiatan tersebut.

Berdasarkan ungkapan metaforis menyisakan kekecewaan penulis dapat memformulasikan konstruksi yang mengandung konsep target dan sumber, yaitu kekecewaan adalah makanan. Berdasarkan konstruksi itu, penulis dapat menyimpulkan bahwa metafora memiliki dua ranah, yaitu: sumber dan target. Yang menjadi sumber dalam metafora itu adalah makanan atau entitas lain yang dapat digunakan berupa makanan tidak enak atau porsi makanan yang banyak, sedangkan yang menjadi target adalah kekecewaan yang mengacu pada benda abstrak. 


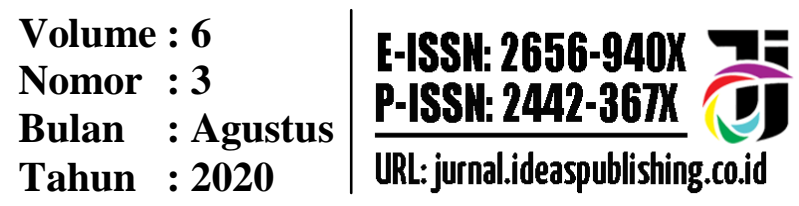

Ungkapan metaforis menyisakan kekecewaan pada contoh di atas juga menyiratkan adanya strategi kesantunan yang direfleksikan dengan tidak langsung, yaitu mengindahkan kosakata untuk membuat pesan yang disampaikan terlihat menarik. Dengan ketidaklangsungan maksud yang dapat diinterpretasikan dari ungkapan metaforis, ungkapan metaforis itu dipilih, karena dengan ungkapan itu, penulis surat pembaca dapat menjaga muka pihak yang menjadi sasaran komunikasi.

Selain itu, ungkapan metaforis mengindikasikan adanya proses kognitif yang dilakukan manusia. Perhatikan contoh (2) berikut.

2) 2208 WARGA BOALEMO TERDAMPAK BANJIR

Radar Gorontalo.com - Saat ini BPBD Kabupaten Boalemo masih melakukan evakuasi terhadap korban, juga mendata dan mendistribusikan bantuan logistik. Sutopo menerangkan gerimis dapat menaikan kembali tinggi genangan air.

Dalam contoh (2) di atas, terdapat ungkapan metaforis yang dapat diinferensikan bahwa gerimis adalah orang yang mengangkat. Kata gerimis disandingkan dengan manusia yang dapat mengangkat sesuatu. Ungkapan gerimis tidak akan terlihat metaforis apabila disandingkan dengan ungkapan orang, karena dengan mengganti kata gerimis dengan orang, kita dapat membuktikan bahwa tingginya genangan air dapat dinaikkan oleh orang. Ada yang dikonseptualisasikan ketika kata gerimis disandingkan dengan kata menaikkan kembali. Penggunaan ungkapan gerimis dalam contoh (2) di atas menjadikan ungkapan menaikkan_menjadi metaforis. Apabila ungkapan menaikkan_disandingkan dengan kata orang, maka ungkapan itu terlihat tidak metaforis, karena ungkapan itu secara konvensional telah diberlakukan bahwa kata menaikkan biasanya disandingkan dengan kata orang atau manusia yang memiliki fitur [+dapat mengangkat]. Hal ini dapat diinferensikan bahwa penulis mengonseptualisasikan bagaimana tindakan menaikkan kembali tinggi genangan air divisualisasikan seperti tindakan manusia/orang yang dapat menaikkan atau mengangkat sesuatu, bagaimana manusia memiliki kekuatan untuk mengangkat sesuatu. Ungkapan gerimis menaikkan kembali tinggi genangan air berada pada konteks peristiwa banjir.

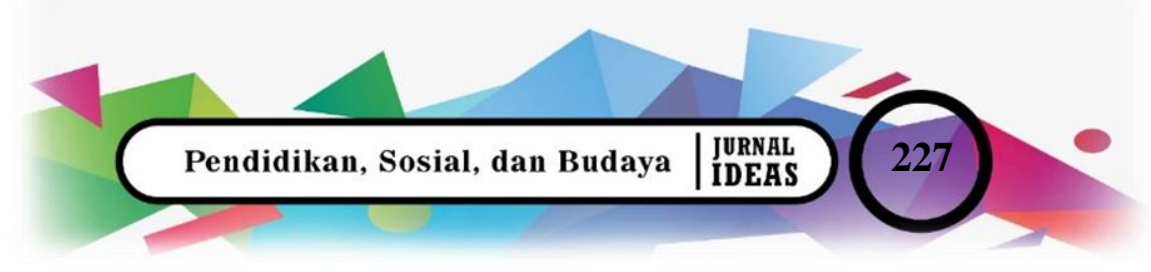


Hal ini dapat dibayangkan apa yang menyebabkan genangan air naik. Dengan gerimis yang turun tersebut alhasil menyebabkan genangan air terus naik. Dalam kaitannya, konseptualisasi yang terlihat dalam kalimat tersebut adalah konsep sebab dan akibat, yaitu gerimis yang turun sebagai sebab dan genangan air yang naik kembali adalah akibat.

Berdasarkan contoh (2) di atas dapat disimpulkan bahwa penulis wacana surat kabar mengonstruksikan pengalaman, perasaan, dan gagasan melalui ungkapan metaforis. Metafora digunakan penulis untuk memikirkan apa yang dialami, dirasakan, dan dipikirkan. Ungkapan metaforis yang diindikasikan melalui contoh-contoh di atas dapat ditarik benang merah dengan bentuk pengalaman, perasaan, dan pikiran yang berada dalam lingkup kehidupan sehari-hari.

Terkait dengan beberapa sitiran wacana dalam bentuk ungkapan metaforis di atas, surat kabar ditulis sebagai bentuk representasi gambaran realita yang dialami, perasaan yang dimiliki, gagasan dan harapan yang ingin disampaikan kepada pembaca baik secara individu, kelompok atau lembaga, dan persoalan yang mungkin membutuhkan penyelesaian. Ketika hal ini dimuat di harian surat kabar, wacana itu memiliki jangkauan pembaca yang tidak terbatas karena sifatnya salah satu rubrik dalam media massa. Walaupun bentuk wacana itu hanya ditujukkan kepada seseorang, surat kabar itu akan menjadi konsumsi publik yang tentunya dapat diketahui oleh siapa saja yang membacanya. Untuk itu, keberadaan ungkapan metaforis dalam wacana surat kabar di atas menyiratkan adanya fakta di luar ungkapan-ungkapan metaforis yang digunakan penulis.

\section{Metode}

Penelitian ini menggunakan jenis penelitian kualitatif deskriptif. Metode kualitatif deskriptif adalah salah satu metode penelitian yang bertujuan untuk menggambarkan data secara kualitatif dan faktual sesuai dengan fakta-fakta, sifat-sifat, serta hubungan antara fenomena yang diselidiki.

Sumber data dalam penelitian ini dibagi menjadi dua bagian, yaitu sumber data primer dan sekunder. Sumber data primer yaitu kumpulan artikel Gorontalo Pos Online yang mengandung unsur metaforis dalam setiap laman artikelnya. Sementara itu, 
Volume : 6

Nomor : 3

Bulan : Agustus

Tahun : 2020

E-ISSH: $2656-940 \mathrm{X}$

P-ISSH: 2442-367X

URL:jurnal.ideaspublishing.co.id

sumber data sekunder yaitu informasi yang mendukung pada permasalahan penelitian berupa kajian pustaka atau buku yang mendukung penelitian.

\section{Hasil dan Pembahasan}

Sutedi (2003:5) mengartikan metafora adalah gaya bahasa yang digunakan untuk mengumpamakan sesuatu hal (misalnya A) dengan hal yang lain (misalnya B), karena adanya kemiripan atau kesamaannya. Lakoff \& Johnson (1980:153) menggambarkan bahwa metafora bisa dinyatakan dalam bentuk "(A)....is...(B)...", sedangkan dalam bahasa Indonesia bisa dipadangkan dengan “...(A)..adalah..(B)..”. Tentunya hal ini bukan merupakan suatu ungkapan yang menyatakan pasti, bahwa $A$ adalah $100 \%$ B. Hal ini justru hanya perumpamaan saja, sebagai pembeda dengan gaya bahasa simile yang biasanya digunakan kata seperti, bagaikan, dan sebagainya.

Proses konseptualisasi yang terjadi dalam metafora yang diformulasikan dari ungkapan metaforis yang proses pembentukannya disesuaikan dengan konteks baik yang mengacu pada situasi fisik terjadinya penggunaan bahasa maupun situasi kejiwaan yang memicu penggunaan bahasa. Dengan mengacu pada teori metafora yang diprakarsasi oleh Lakoff \& Johnson dalam karyanya Metaphor We Live By (1980:203) yang telah direvisi dan dicetak ulang dalam rentang waktu lebih dari dua dekade, yang tetap mempertahankan konsep awal dalam teori metafora konseptual bahwa metafora merefleksikan apa yang dipikirkan, dialami, dan apa yang dirasakan dalam kehidupan sehari-hari (Lakoff \& Johnson, 2003, p. 3). Adapun revisi yang dilakukan Lakoff dan Johnson adalah berkaitan dengan pembagian jenis metafora yang terdiri atas orientational 'orientasional', ontological 'ontologis', dan structural 'struktural' (Lakoff \& Johnson, Metaphors We Live By, 2003, p. 264).

Keduanya berpendapat bahwa pembagian metafora di atas bersifat semu sebab metafora pada dasarnya berorientasi secara struktural karena dapat memetakan struktur ke struktur, semua metafora adalah ontologis karena mereka menciptakan entitas ke ranah target, dan banyak metafora yang orientasional karena mereka mereka memetakan image-schemes yang orientasional.

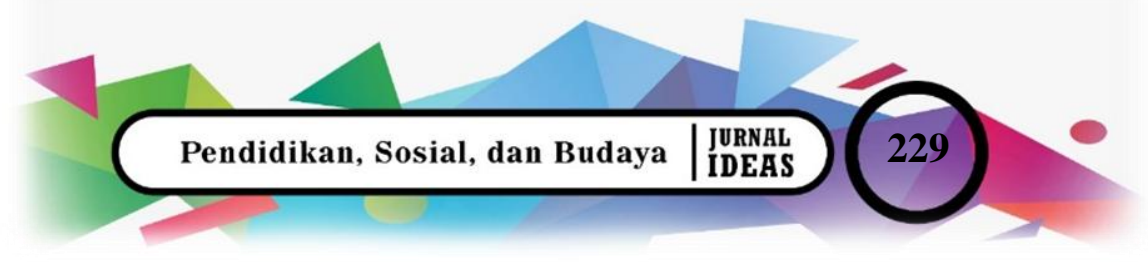




\section{Metafora Ontologis}

Lakoff \& Johnson (1980:25-26) menjelaskan bahwa metafora ontologis merupakan salah satu jenis metafora yang melihat kejadian, aktifitas emosi, dan ide sebagai entitas dan substansi. Misalnya dalam konsep metafora "THE BRAIN IS A MACHINE" dalam kalimat dalam kalimat "My brain is not operating well today" (hari ini otak saya tidak bekerja dengan baik atau hari ini saya sedang tidak ingin berpikir). Kalimat ini menjelaskan bahwa otak disamakan dengan mesin yang dapat mengoperasikan sesuatu. Padahal, jika dikaitkan dengan situasi nyata, otak bukan merupakan entitas konkret yang dapat berfungsi untuk mengoperasikan sesuatu. Kata operating dalam kalimat tersebut yang mempengaruhi peran kata brain (otak) sebagai nomina abstrak menjadi nomina konkret, dan merubah peran dan fungsi otak sebagai mesin. Untuk itu, dalam kalimat ini, metafora ontologis berorientasi pada konsep pikiran, pengalaman, dan proses atau hal abstrak lainnya ke sesuatu yang memiliki sifat fisik. Dengan kata lain, metafora ontologis ini dikenal sebagai bentuk konseptualisasi nomina abstrak sebagai nomina konkret atau mereplikasi bentuk nomina abstrak ke nomina konkret. Berikut ini contoh metafora kenaikan harga barang yang dipandang sebagai suatu entitas melalui nomina inflasi.

INFLATION IS AN ENTITY (Inflasi adalah sebuah kesatuan)

Inflation is lowering our standard of living

(inflasi menurunkan standar kehidupan kita)

Inflation makes me sick

(inflasi membuat saya muak)

Berdasarkan contoh metafora inflasi tersebut, suatu entitas mengacu pada hal tersebut (referring), menghitung jumlahnya (quantifying), mengidentifikasi aspek tersebut (identifying aspects), mengidentifikasi penyebab/alasannya (identifying causes), menentukan tujuan dan mendorong tindakan (setting goals and motivating actions) (Lakoff \& Johnson, 1980:26). Contoh lain dapat dilihat melalui surat kabar harian Gorontalo berikut ini. 
Volume : 6

Nomor : 3

Bulan : Agustus

Tahun : 2020

E-ISSH: 2656-940X

P-ISSH: 2442-367X

URL:jurnal.ideaspublishing.co.id

3) Pengaktifan Kades Lombongo Menuai Protes, Ricuh dan Nyaris Adu Jotos

Hargo.co.id, GORONTALO - Permasalahan antara Kepala Desa Lombongo Zulkifli Abdulah dan masyarakatnya, pada April 2018 silam kembali memanas. Setelah konflik yang sebelumnya berbuntut penonaktifan sementara Kepala Desa Lombongo itu mereda, Kamis (14/02/2019), gejolak itu pun kembali menyulut hingga memicu kericuhan.

Pada contoh (3) di atas terlihat bahwa adanya bentuk konsep +GEJOLAK ADALAH API+. Kalimat tersebut mengindikasikan peran emosi sebagai bentuk entitas abstrak berubah peran sebagai entitas konkret, dalam hal ini gejolak (entitas abstrak) menjadi seperti api (entitas konkret). Hal ini dipengaruhi oleh verba menyulut atau sama halnya dengan menyala yang mempengaruhi perubahan peran dari kata gejolak menjadi seperti api.

\section{Metafora Orientasional}

Metafora orientasional merupakan metafora yang berkaitan dengan orientasi ruang, seperti naik-turun, dalam-luar, depan-belakang, dan lain-lain. Lakoff \& Johnson menjelaskan bahwa dalam metafora orientasional, sebagian besar ekspresi tidak dapat dilihat sebagai bentuk metafora (Lakoff \& Johnson, 2003, p. 14). Hal ini berkaitan dengan benda non fisik dipandang sebagai entitas atau substansi yang berhubungan dengan orientasi ruang, seperti naik-turun, dalam-luar, dan lain-lain. Metafora ini lebih didasarkan pada pengalaman fisik manusia dalam mengatur orientasi arah dalam kehidupan sehari-hari, seperti UP-DOWN yang diukur dari pengalaman fisik manusia. Metafora orientasional merefleksikan konsep spasial yang berbeda-beda menurut pengalaman fisik atau budaya masyarakatnya. Oleh karena itu, sudut pandang metafora orientasional berbeda di setiap budaya, karena apa yang dipikirkan, dialami, dan dialami oleh budaya tertentu akan berbeda.

Lakoff \& Johnson (2003, p. 14) memberikan contoh metafora orientasional pada konsep +HAPPY IS UP. Dalam kalimat ini, kata happy (bahagia) diorientasikan dengan kata up (ke atas). Artinya, ketika seseorang merasa bahagia sama halnya memiliki orientasi ke atas, seperti dalam kalimat "I'm feeling up today" (saya merasa bahagia hari ini). Kalimat ini mengindikasikan perasaan bahagia yang diibaratkan dengan kata up. Dalam kalimat ini, kata up diindikasikan sebagai makna 'bahagia' karena dipengaruhi secara langsung oleh kata feeling (merasakan) sehingga pastinya kata yang berada di 
sekitar kata feeling tersebut tidak jauh bergeser dan berkaitan dengan perasaan yang melingkupinya.

Bentuk metafora orientasional yang telah dikonsepkan di atas tidak hanya ditemukan dalam konteks bahasa inggris, melainkan metafora orientasional juga dapat ditemukan dalam budaya lain, termasuk dapat ditemukan dalam wacana surat kabar pada umumnya. Berikut ini contoh metafora orientasional yang ditemukan dalam surat kabar harian Gorontalo:

4) Puas Akan Kemenangan Dikandang, Persidago Harus Berbenah Diri

Hargo.co.id Gorontalo- Pasalnya dilihat dari kasta, Persidago berada dibawah dua tingkat dari Persipuran yang saat ini sudah bermain di Liga I sedangkan Persidago berada pada Liga III. "Ini merupakan kebanggan bagi masyarakat Gorontalo karena dapat menjadi penghuni papan atas klasemen. Peripura yang sudah tampil pada liga Asia, bisa lalan dengan tim kebanggaan kita yang hanya ada liga III. Kita berharap kemenangan ini bisa lebih memotivasi para pemain untuk menghadapi Persipura pada laga tandang nantinya," tutupnya. (ded/hg)

Sitiran tajuk di atas mengindikasikan bentuk metafora yang berorientasi pada konsep +BAWAH ADALAH JELEK; +ATAS ADALAH BAIK. Misalnya pada kalimat Persidago berada dibawah dua tingkat dari Persipura. Dalam kalimat ini, orientasi kata bawah bermakna jelek karena dipengaruhi oleh posisi Persidago dalam pertandingan sepak bola mendapat skor yang rendah dari Persipura sehingga hal ini dinilai jelek dari apa yang diharapkan. Sebaliknya pada kalimat karena dapat menjadi penghuni papan atas klasemen. Dalam konstruksi kalimat ini, kata atas diindikasikan sebagai makna baik karena dalam kalimat tersebut posisi Persidago berhasil menduduki posisi yang lebih baik dari yang diharapkan. Untuk itu, konsep bawah dan atas diorientasikan sebagai makna jelek dan baik.

\section{Metafora Struktural}

Metafora struktural merupakan konsep yang dibentuk secara metaforis dengan menggunakan konsep yang lain. Metafora struktural ini didasarkan pada dua ranah, yaitu ranah sumber dan ranah sasaran. Metafora struktural memungkinkan kita untuk melakukan lebih dari sekadar mengorientasikan konsep, merujuk padanya, mengukurnya, dan lain-lain, seperti yang kita lakukan dengan metafora orientasi dan 


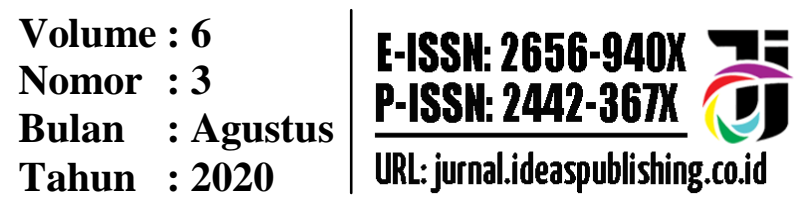

ontologis sederhana; namun metafora struktural merujuk untuk menggunakan satu konsep yang sangat terstruktur dan jelas digambarkan untuk menyusun konsep yang lain. Metafora ini didasarkan pula pada korelasi sistematis dalam pengalaman seharihari. Kovecses (2010:37) mencontohkan konsep waktu yang disusun berdasarkan gerak dan ruang. Mengingat waktu adalah metafora gerak, kita memahami waktu dengan cara berikut ini.

Time Is Money

a. You're wasting my time

b. This gadget will save you hours

c. I don't have the time to give you

d. How do you spend your time these day?

e. The flat tire cost me an hour (Lakoff \& Johnson, 1980:, p. 7-8)

Dalam konstruksi kalimat di atas dijelaskan oleh Lakoff \& Johnson (1980) bahwa antara time dan money mempunyai kesamaan atau kemiripan. Kesamaan antara waktu dan uang merupakan sesuatu yang penting dalam kehidupan manusia dan sulit untuk meraihnya. Dari contoh in metafora struktural menampilkan satu konsep yang secara metaforis terstruktur yang merujuk ke bentuk yang lain. Cara yang digunakan ini adalah memetakan konsep antara elemen-elemen dalam A dan elemen-elemen dari B.

Berdasarkan contoh di atas, konsep metafora struktural juga ditemukan dalam wacana surat kabar pada umumnya, yang dapat dipetakan secara skematis +WAKTU ADALAH UANG+ seperti nampak pada beberapa sitiran wacana Harian Gorontalo berikut ini:

\section{Rapat di Pantai Ratu, FH Unisan Disambut Hangat Bupati}

Hargo.co.id, GORONTALO- Pantai Kota Ratu bukan saja jadi tujuan wisatawan menghabiskan waktu libur. Namun, wisata dengan keindahan alam itu kini banyak dimanfaatkan sebagai lokasi pertemuan atau rapat berbagai instansi atau lembaga (Sabtu, 18/01/2020)

\section{Panas! Madrid Ancam Catalunya, Beri Waktu sampai Senin}

Hargo.co.id. GORONTALO- Yakni, apakah penandatanganan berkas itu setara dengan deklarasi kemerdekaan. Madrid memberikan waktu sampai Senin $(16 / 10)$ kepada Puigdemont untuk menjelaskan sikapnya (13/10/2017) 


\section{Masuk Hutan dan Butuh Waktu 3 Jam BNN Mendapati Landang Ganja} Ini

Hargo.co.id.GORONTALO- Sementara itu, untuk mencapai lokasi kedua lading ganja tersebut diperlukan waktu sekitar tiga jam menembus hutan dan mendaki gunung dengan kemiringan sekitar 30-45 derajat. (19/4/2016).

Dari tiga sitiran di atas, konstruksi kalimat yang digarisbawahi menegaskan bahwa waktu dipetakan memiliki kemiripan atau kesamaan dengan uang. Sitiran (5) menjelaskan bahwa 'wisatawan menghabiskan waktu'. Dalam kalimat ini, konstruksi menunjukkan bahwa waktu diumpamakan menyerupai benda konkret yang dapat dihabiskan dalam sekejap saja. Sama halnya dengan konstruksi kalimat sitiran (6) dan (7) waktu disamakan dengan benda konkret yang dapat diberikan dan dipegang oleh setiap orang, dan waktu pula dapat diumpamakan seperti benda yang sangat diperlukan dalam sesaat. Hal ini yang akhirnya mendasari pemetaan konsep metafora bahwa waktu (benda abstrak) dinilai seperti uang (benda konkret) yang sangat diperlukan oleh setiap orang, yang dapat dihabiskan dan diberikan begitu saja.

\section{Bentuk Lingual Ungkapan Metaforis}

Sebagai sebuah bentuk ungkapan, metafora memiliki bagian-bagian sebagai unsur atau komponen pembangunnya. Deignan (Deignan, 2005, p. 148) berpendapat bahwa bentuk lingual ungkapan metaforis dapat bervariasi secara sintaksis, misalnya nomina, verba, dan adjektiva. Secara umum, makna metaforis juga tidak hanya dikaitkan dengan bentuk sintaksis saja, tetapi juga ada unsur non-metaforis yang dapat dikaitkan dengan bentuk metaforis. Oleh karena itu, metafora dapat berkaitan dengan proses kognitif. Lakoff (2006) berpendapat bahwa metafora adalah cara mengasosiasikan suatu konsep dengan konsep yang lain dengan bahasa. Hal ini dijelaskan pula oleh Kovecses (Kovecses, 2006, p. 116) bahwa metafora merefleksikan apa yang dipersepsikan, dialami, dan dipikirkan orang tentang kenyataan dunia. Dari pernyataan ini dapat dikatakan bahwa metafora berkaitan dengan persepsi manusia terhadap apa yang dipikirkan dan dirasakannya. 
Volume : 6
Nomor : 3
Bulan : Agustus
Tahun : 2020

E-ISSH: 2656-940X

P-ISSH: 2442-367K

URL:jurnal.ideaspublishing.co.id

Berdasarkan kategori sintaksisnya, Deignan (Deignan, 2005, p. 148) menegaskan bahwa bentuk lingual metafora bervariasi, misalnya nomina, verba, dan adjektiva. Hal ini dicontohkan dalam bentuk kalimat berikut ini.

1. Her self-esteem was shaken by a move and a new job

'Harga dirinya digoyang oleh mutasi dan pekerjaan baru' (2005:149);

2. She made him blush by telling dirty jokes

'Ia membuatnya tersipu-sipu dengan kata-kata kotor' (2005:151);

3. I always thought her a mouse

'Saya selalu berpikir ia seekor tikus' (2005:153).

Ungkapan was shaken, dirty, dan mouse merupakan ungkapan metaforis yang berbentuk lingual verba, adjektiva, dan nomina secara berurutan. Dalam tulisan yang berbeda, Deignan (Deignan, 2006, p. 109) menyatakan bahwa apabila dibandingkan dengan makna literalnya, ungkapan metaforis kadang berubah kategori sintaksisnya. Sebagai contoh kata squirrel dalam klausa berikut, ... as consumers squirrel away huge sums for the downpayment on a home '... karena para konsumen mengambil uang yang banyak secara diam-diam dan berkali-kali untuk mengangsur rumahnya', ungkapan squirrel yang biasanya berkategori nomina, dalam contoh itu kata squirrel berubah menjadi verba yang digunakan untuk mengacu suatu tingkah laku yang dilakukan oleh binatang yang diacu, yaitu: tupai.

Dalam memahami konsep metafora di atas, kita dapat menggunakan kata 'untuk memahami' dalam menggambarkan hubungan antara dua konsep (a dan b) dalam proses metaforis. Sebab dalam memahami makna sebuah kata tidak hanya sebatas merujuk pada makna sebenarnya, namun ada unsur kontekstual yang menyertai makna sebuah kata dalam suatu kalimat. Kovecses menjelaskan bahwa ada unsur korespondensi sistematis antara ranah sumber dan target dalam makna suatu kata, atau dalam arti ada unsur konseptual konstituen b yang sesuai dengan konstituen elemen a. Secara teknis, korespondensi konseptual ini sering disebut sebagi pemetaan (Kovecses, 2010, p. 7).

Akan tetapi, dalam memahami unsur metaforis dalam sebuah kata tidak hanya sebatas dikatakan sebagai bentuk pemahaman. Ada unsur konvensional yang menyertai karakterisasi metafora secara konseptual. Hal ini dicontohkan oleh Kovecses dalam kalimat 'Live as a journey' (Hidup sebagai sebuah perjalanan) (Kovecses, 2010, p. 8). 
Contoh ini tidak hanya merujuk pada makna literal seperti yang terlihat dalam kalimat tersebut, tetapi ada referen yang merujuk ke makna lain sesuai dengan konteks kalimat itu digunakan. Pandangan inilah yang menjelaskan bahwa metafora konseptual tidak hanya sekedar dimaknakan sebagai konsep memahami, tetapi metafora juga menyertai unsur konvensional di dalamnya.

Mari kita perhatikan contoh pemetaan ranah sumber kepada ranah target, dalam konsep metafora +LOVE IS JOURNEY+ (Cinta adalah Perjalanan) (lihat Kovecses, 2010, p. 8). Ketika kita menggunakan kalimat we aren't going anywhere (kita tidak pergi kemana saja), ungkapan go anywhere (pergi kemana saja) menunjukkan perjalanan ke suatu tempat, tetapi tujuan tempat yang dimaksud tidak nampak dengan jelas. Sementara itu, kata we (kita) merujuk pada pelancong. Dari bentuk kalimat tersebut, terdapat tiga elemen utama yang menjadi referennya, yaitu: pelancong, perjalanan, dan tujuan (tempat). Namun, ketika unsur kalimat ini merujuk pada konteks yang berbeda berupa cinta, maka unsur kalimat yang terdapat didalamnya seperti pelancong tidak merujuk pada makna yang sebenarnya tetapi lebih mengacu pada makna kekasih, perjalanan lebih merujuk pada peristiwa dalam hubungan cinta, dan tujuan lebih mengarah pada tujuan hubungan cinta.

Berdasarkan penjelasan sebelumnya, bentuk lingual ungkapan metaforis yang dimaksudkan dalam buku ini berbeda dengan bentuk lingual metafora yang diajukan Halliday (2004) yang dinamakan metafora gramatikal. Menurut Halliday, representasi metafora gramatikal terpadu dalam suatu struktur yang menunjukkan adanya perubahan lapisan makna dan susunan kata (Haliday, 2004, p. 626). Dengan demikian, metafora gramatikal diperoleh dari perubahan bentuk atau kombinasi antarkata dalam tuturan. Halliday mencontohkan ungkapan I think 'Saya pikir/kira' berbeda dengan I thoguht dan it is likely that 'tampaknya' mengimplikasikan mengandung lapisan makna yang berbeda. Perbedaan makna terjadi karena perbedaan kata yang digunakan atau karena susunan kata yang dihasilkan. Apabila dibandingkan dengan bentuk lingual metafora yang diungkapkan dalam tulisan ini, metafora gramatikal yang dikemukakan Halliday ada kesamaannya dalam hal perubahan bentuk atau kategori sintaksis kata dapat menimbulkan perubahan lapisan makna suatu tuturan. Seperti contoh yang diberikan Deignan, kata squirrel yang berupa nomina yang berarti tupai, ketika berubah kategori 
Volume : 6

Nomor : 3

Bulan : Agustus

Tahun : 2020

sintaksisnya menjadi verba, memiliki makna tambahan, yaitu: tindakan yang menyerupai tupai (Deignan, 2005). Akan tetapi, ada perbedaan penekanan dalam tulisan ini, yaitu: bahwa tambahan makna yang dimaksudkan adalah konseptualisasi atas suatu konsep dengan konsep lainnya.

Dalam penelitian ini, kita akan menjelaskan bagaimana perubahan kategori sintaksis kata yang dapat mengakibatkan kata yang tidak metaforis menjadi ungkapan yang metaforis. Seperti halnya dalam kata squirrel yang berarti tupai dapat dikategorikan sebagai nomina, tetapi apabila kata itu berkonversi menjadi verba, kata itu berubah menjadi metaforis. Dari pernyataan ini, Danial menegaskan bahwa makna sebuah kata dapat dipengaruhi oleh konstruksi yang menyertainya (Danial, 2014, p. 21). Lebih lanjut, Danial mencontohkan nomina hand yang berkonstruksi menjadi verba (Danial, 2014, p. 47). Perubahan gramatikal leksem hand menjadi verba merubah makna kata tersebut menjadi to give 'memberikan'. Perbedaan skematis yang mendasar antara makna literal hand berkelas gramatikal nomina dan makna perluasan hand yang berkelas gramatikal verba dapat dipahami, yaitu nomina secara konseptual menjelaskan benda, sedangkan verba menjelaskan variasi hubungan. Secara semantic, kelas gramatikal hand sebagai nomina mengacu pada makna 'tangan', dan sebagai verba bisa menguraikan predikat putatif, yaitu verba instrument yang mengacu pada skema 'pergerakan' (Driven, 1999, p. 282).

Suatu konstruksi gramatikal menurut Langacker adalah suatu gabungan struktur simbolik yang padu antara dua komponen atau lebih yang dimanifestasikan oleh struktur semantis dan fonologis (Langacker, 2002, p. 23). Dari definisi yang diberikan Langacker, apabila dilihat dari bentuknya, konstruksi gramatikal dapat mengacu pada susunan yang berupa kata yang mengandung dua morfem atau lebih, atau berupa frase yang mengandung dua kata atau lebih atau susunan yang lebih besar yaitu klausa. Dengan demikian, konstruksi gramatikal leksem tertentu dalam sebuah kalimat dapat mempengaruhi peran fungsional semantic secara menyeluruh. Mekanisme kognitif alamiah yang dimiliki manusia menjadi faktor perubahan makna pada leksem tertentu. Hal ini yang akhirnya menimbulkan munculnya gaya bahasa seperti metafora sebagai bentuk perluasan makna pada leksem tertentu.

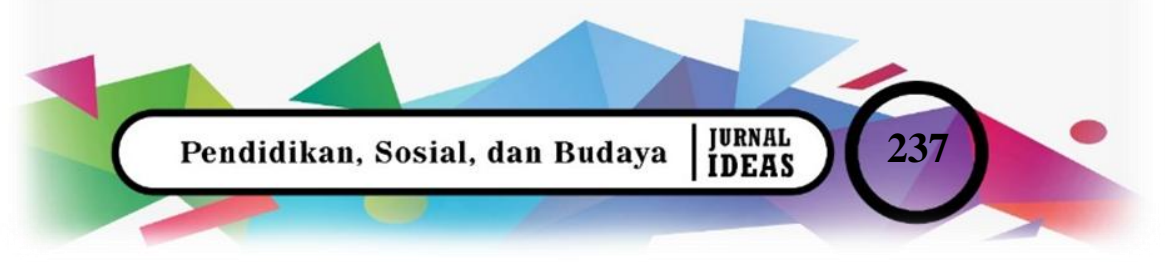


7F E-ISSH: 2656-940X

(1) P-ISSH: 2442-367K

URL:jurnal.ideaspublishing.co.id
Volume : 6

Nomor : 3

Bulan : Agustus

Tahun : 2020

\section{Simpulan}

Dalam kegiatan sehari-hari, metafora dipahami sebagai sistem konsep yang mengimplikasikan apa yang kita rasakan, apa yang kita pikirkan, dan apa yang kita lakukan. Hal ini secara eksplisit menegaskan bahwa metafora bukan hanya meresap dalam bahasa yang digunakan sehari-hari melainkan metafora juga berada dalam pikiran dan tindakan. Proses konseptualisasi yang terjadi dalam metafora yang diformulasikan dari ungkapan metaforis yang proses pembentukannya disesuaikan dengan konteks baik yang mengacu pada situasi fisik terjadinya penggunaan bahasa maupun situasi kejiwaan yang memicu penggunaan bahasa

Secara konseptual, metafora dibagi menjadi tiga bentuk yaitu metafora ontologis, orientasional, dan struktural. Dari segi bentuknya, metafora dalam wacana surat kabar memiliki bentuk yang khas yang ditunjukkan oleh kata dasar dan bentukan yang mendukung terbentuknya ungkapan metaforis. Hal ini dapat dikaitkan dengan konsep bahwa metafora merefleksikan apa yang dipersepsikan, dialami, dan dipikirkan orang tentang kenyataan dunia. Dari pernyataan ini dapat dikatakan bahwa metafora berkaitan dengan persepsi manusia terhadap apa yang dipikirkan dan dirasakannya.

\section{Daftar Rujukan}

Boeree, C. (2006). Abraham Maslow 1908-1970. Retrieved from Shipensburg University: webspace.ship.edu/cgboer/maslow.html/

Danial, H. (2014). Perluasan Makna Leksem Hand. Universitas Gajah Mada. Yogyakarta: Tidak diterbitkan.

Deignan, A. (2005). Metaphor and Corpus Linguistik. Amsterdam: Benjamins Publishing.

Deignan, A. (2006). The Grammer of Linguistics Metaphors. (A. Stefanowitsch, \& S. T. Gries, Eds.) Mouton de Gruyter.

Djawanai, S. (1999). Telaah Bahasa, Telaah Manusia. Pidato Pengukuhan jabatan Guru Besar dalam Ilmu Linguistik. Yogyakarta.

Haliday, M. (2004). AN Introduction to FUnctional Grammar. New York: Oxford University Press.

Kittay, E. (1987). Metaphor: Its Cognitive Force and Linguistic Structure. Oxford: Clarendon Press.

Kovecses, Z. (2002). Metaphor. A Practical Introduction. Oxford: Oxford University. Kovecses, Z. (2006). Language, Mind, and Culture. Oxford: Oxford University Press. Kovecses, Z. (2010). Metaphor. A Practical Introduction. Oxford : Oxford University Press.

Lakoff, G., \& Johnson, M. (1999). Philosophy in the Flesh: the Embodied Mind and its Challenge to Western Thought. New York: Basic Book. 
Volume : 6

Nomor : 3

Bulan : Agustus

Tahun : 2020

E-ISSH: 2656-940X

P-ISSH: 2442-367K

URL: jurnal.ideaspublishing.co.id

Lakoff, G., \& Johnson, M. (2003). Metaphors We Live By. Chicago dan London: The University of Chicago Press.

Langacker, R. (2002). Concept, Image, and Symbol. The Cognitive Basis of Grammar. New York: Mouton de Gruyter.

Panther, K., \& Radden, G. (2003). Metonymy in Language and Thought.

Amsterdam/Philadelphia: John Benjamins.

Taylor, J. (2003). Cognitive Grammar. New York: Oxford University Press. 


\begin{tabular}{|c|c|}
\hline $\begin{array}{l}\text { E-ISSH: } 2656-940 X \\
\text { P-ISSH: } 2442-367 K\end{array}$ & $\begin{array}{l}\text { Volume : } 6 \\
\text { Nomor : } 3 \\
\text { Bulan }\end{array}$ \\
\hline URL: jurnal.id & Tahun : 2020 \\
\hline
\end{tabular}

